\title{
3 Research Square

\section{Morphological and Ecological Features of Some Nematodes of the Genus Rhabdochona in Marinka Obtained From Fergana Valley, Uzbekistan}

\author{
Abdurakhim Kuchboev ( $\square$ abdurakhim.kuchboev@mail.ru ) \\ Institute of Zoology of the Academy of Sciences of the Republic of Uzbekistan \\ Eldor Kh Najmidinov \\ Ferganskij gosudarstvennyj universitet: Farg'ona davlat universiteti \\ Muzaffar A Mukhamediev \\ Ferganskij gosudarstvennyj universitet: Farg'ona davlat universiteti

\section{Rokhatoy R Karimova} \\ Institute of Zoology UzAS: Institute of Zoology of the Academy of Sciences of the Republic of \\ Uzbekistan

\section{Kader Yildiz} \\ Kirikkale University Faculty of Veterinary Medicine: Kirikkale Universitesi Veteriner Fakultesi
}

\section{Research Article}

Keywords: morphology, ecology, nematodes, common marinke, Rhabdochona

Posted Date: March 23rd, 2021

DOI: https://doi.org/10.21203/rs.3.rs-341355/v1

License: (c) (1) This work is licensed under a Creative Commons Attribution 4.0 International License. Read Full License 


\section{Abstract}

The aim is to study the morphological and ecological features of some nematode species of the genus Rhabdochona parasites of marinka fish in the Fergana Valley, Uzbekistan. Rhabdocona gnedini, Rhabdochona denudata and Rhabdocona hellichi turkestanica were detected as 5.3\%, 7.9\% and 3.7\%, respectively. According to the Authors' knowledge, Rh. hellichi turkestanica was recorded in Uzbekistan and Central Asian republics for the first time. Rhabdocona spp. were only detected in the intestine of marinkas lived in the mountain rivers Rezaksay, Chodaksay and small tributaries of the Syrdarya river in western Fergana. Some abiotic factors such as the flow rate, water temperature and high content of dissolved oxygen in it, as well as the nutritional characteristics of the fish can be most important factors to spread of Rh.denudata, Rh. gnedini, Rh. hellichi turkestanica in marinkas from mountain rivers of the Fergana Valley.

\section{Introduction}

Among the 87 fish species currently registered in the ichthyofauna of Uzbekistan, more than 26 species are of commercial importance, of which the common marinka is of particular interest - a typical representative of the Mountainous Asian complex of ichthyofauna, which is widespread in the mountain rivers of the upper reaches of the Syrdarya (Mukhamediev 1982). The results of recent studies have established that the common marinka, called as Schizothorax intermedius and living in the mountain rivers of the Fergana Valley, is genetically identical to the morphology of Schizothorax eurystomus, regularly mentioned by the authors since 1872 , but there is still a considerable amount of identification work to finally prove this version. Among the river forms of the marinka fished from the Isfairamsay river, there are also individuals with traits of lake fish living in places with more diverse feeding conditions, which indicates a high morpho-ecological variability of the species (Mukhamediev 1982). In this regard, it should be noted that as a result of anthropogenic impact, the river flow of the region decreased somewhat, which in turn caused negative changes in aquatic ecosystems, primarily expressed in an unfavorable epizootic situation and significant economic damage from the effects of parasites and fish diseases, as well as in a dangerous factor for human health (Karimov 2007).

Some authors previously studied the parasite fauna of reservoirs in the middle reaches and the lower reaches of the Syrdarya river (Osmanov 1971; Karaev 1994; Karimov 2007; Safarova 2017) and they have noted the presence of 35 to 128 species of fish parasites. Karimov (2007) reported 36 species of parasites, of which 10 species belong to Myxosporidia, 7 to ciliates, 11 to trematodes, 4 to nematodes, 2 to cestodes, and 2 to Acanthocephalans in marinka sampled in the waterbodies of the Fergana Valley. The other researcher found 13 helminth species in common marinka lived in various types of waterbodies in the northeast of Uzbekistan (Safarova 2017).

The genus Rhabdochona belong to the order Spirurida, Nematoda (Anderson 2000). The genus $R$ habdochona includes a large number of species that parasitize freshwater fish in the world (Moravec 2010). Eight species of this genus were detected previously in freshwater fish lived in Uzbekistan 
(Akramova et al. 2019). There are also some reports that these parasites have been reported from marinka (Safarova 2017; Karimov 2007). Rhabdochona denudata and Rh. gnedini were recorded from common marinka in the middle reaches of the Syrdarya river in Uzbekistan (Safarova 2017). Rhabdocona denudata and $R h$. heillichi also notes in the waterbodies of Northern Tajikistan (Karimov 2007). Marinka is very popular for local fishing in Uzbekistan. The helminth fauna of marinka in the Fergana Valley has been studied extremely insufficiently. The available data is fragmentary. The aim of this study is to examined the morphological, ecological features and infection of the common marinkas with nematode species of the genus Rhabdochona in the Fergana Valley of Uzbekistan.

\section{Material And Methods}

In the present study, marinka (n:185) was sampled a period between April 2018-October 2020, during the period of intensive post-spawning feeding of the marinka, characterized by the highest probability of infection fish helminths in the mountain rivers and small tributaries of the Syrdarya $\left(40^{\circ} 17^{\prime} 85^{\prime \prime}\right.$ north latitude, $71^{\circ} 58^{\prime} 44^{\prime \prime}$ east longitude), in the mountain rivers Isfairamsay, Sokh, Shakhimardansay located in the south of the Fergana Valley (former tributaries of the Syrdarya), in the Syrdarya - the largest river in Central Asia, as well as in the mountain rivers Chodaksay and Rezaksay, located in the north of the valley (Figure 1).

The fish necropsy was performed according to Bykhovskaya-Pavlovskaya (1985). Simultaneously with the examination of the intestinal tract, a thorough examination of the body cavity and other organs and systems of fish was carried out. The nematodes were obtained from intestines and fixed in $2.0 \%$ formalin and hot $70 \%$ alcohol. Then they were examined using a light microscope (ML 2000, Meiji Tecno Japan), parasite pictures were drawn with a drawing apparatus RA-5 in the laboratory of General Parasitology of the Institute of Zoology of the Academy of Sciences of the Republic of Uzbekistan. To determine the species of parasites were used monographs of authors (Agapova 1962; Chubb 1982; Vismanis et al. 1987) were used.

\section{Results}

In the present study, three species of the genus Rhabdochona (Rhabdochona gnedini, Rh denudata, and Rh. hellichi turkestanica Skrjabin, 1917) were observed in the intestine of the marinkas (n:18) only sampled in the mountain rivers Rezaksay, Chodaksay and small tributaries of the Syrdarya river in western Fergana.

Some morphological measurements of the Rhabdocona species show in the Table. Rhabdochona gnedini (Figure 2) was found in marinka sampled from the small tributaries of the Syrdarya of western of Fergana (5.3\%) and river of Rezaksay (3.0\%) for the first time in the present study. The number of $R h$. gnedini per fish was higher in Syrdarya than that of Rezeksay ( $8 \pm 0.4 \mathrm{vs.} 2 \pm 0.1$ ). The ratio of females to males is $1: 2$ on average. Rhabdochona denudata (Figure 3 ) was found in small tributaries of the Syrdarya of western Fergana (7.9\%). The number of $R h$. denudata per fish was $16 \pm 0.8$. The ratio of 
infected males to females fish averages 1: 3. Rhabdochona hellichi turkestanica (Figure 4) was detected in fish sampled from the tributaries of the Syrdarya in the western of Fergana (3.7\%) and the mountain river Chodaksay in the northern part of the valley (2.0\%). The number of $R h$. hellichi turkestanica per fish was closer in Syrdarya with the Chodaksai River $(3 \pm 0.2 \mathrm{vs.} 3 \pm 01)$. The ratio of females to males is $1: 2$ on average.

Table. Morphological specification of Rhabdochona species 


\begin{tabular}{|c|c|c|c|c|c|c|}
\hline \multirow[t]{2}{*}{$\begin{array}{l}\text { Morphological } \\
\text { criteria (mm) }\end{array}$} & \multicolumn{2}{|c|}{$\begin{array}{l}\text { Rhabdochona } \\
\text { gnedini }(\mathrm{n}=6)\end{array}$} & \multicolumn{2}{|c|}{$\begin{array}{l}\text { Rhabdochona } \\
\text { denudate }(n=6)\end{array}$} & \multicolumn{2}{|c|}{$\begin{array}{l}\text { Rhabdochona hellichi } \\
\text { turkestanica }(\mathrm{n}=3)\end{array}$} \\
\hline & प & प & प & प & प & प \\
\hline \multirow[t]{3}{*}{ Body length } & $7,8 \pm 1.1$ & \multirow{2}{*}{$\begin{array}{l}16.8 \pm \\
1.2\end{array}$} & $4 \pm 0.2$ & \multirow{2}{*}{$\begin{array}{l}13.5 \pm \\
0.5\end{array}$} & $10.45 \pm 0.4$ & $13.3 \pm 0.4$ \\
\hline & \multirow[t]{2}{*}{$5.8-9.8$} & & \multirow[t]{2}{*}{$3-5$} & & \multirow[t]{2}{*}{$9.4-11.5$} & \multirow[t]{2}{*}{$11.2-15.4$} \\
\hline & & $\begin{array}{l}12.2- \\
21.4\end{array}$ & & $12-15$ & & \\
\hline \multirow[t]{3}{*}{ Body width } & $\begin{array}{l}0.1 \pm \\
0.01\end{array}$ & $\begin{array}{l}0.24 \pm \\
0.04\end{array}$ & $\begin{array}{l}0.11 \pm \\
0.02\end{array}$ & $0.22 \pm$ & \multirow{3}{*}{$\begin{array}{l}0.15 \pm 0.02 \\
0.14-0.16\end{array}$} & \multirow{3}{*}{$\begin{array}{l}0.24 \pm 0.03 \\
0.21-0.28\end{array}$} \\
\hline & & & & & & \\
\hline & $\begin{array}{l}0.08- \\
0.12\end{array}$ & $\begin{array}{l}0.18- \\
0.30\end{array}$ & $0.1-0.12$ & $\begin{array}{l}0.20- \\
0.25\end{array}$ & & \\
\hline \multirow[t]{2}{*}{ Prostom length } & $\begin{array}{l}0.025 \pm \\
0.002\end{array}$ & $\begin{array}{l}0.035 \pm \\
0.003\end{array}$ & $\begin{array}{l}0.016 \pm \\
0.001\end{array}$ & $\begin{array}{l}0.025 \pm \\
0.002\end{array}$ & $\begin{array}{l}0.024 \pm \\
0.002\end{array}$ & $\begin{array}{l}0.028 \\
\pm 0.002\end{array}$ \\
\hline & $\begin{array}{l}0.02- \\
0.03\end{array}$ & $\begin{array}{l}0.03- \\
0.04\end{array}$ & $\begin{array}{l}0.015- \\
0.018\end{array}$ & $\begin{array}{l}0.02- \\
0.03\end{array}$ & $0.021-0.027$ & $0.026-0.035$ \\
\hline \multirow[t]{2}{*}{ Prostom wide } & $\begin{array}{l}0.016 \pm \\
0.001\end{array}$ & $\begin{array}{l}0.025 \pm \\
0.002\end{array}$ & $\begin{array}{l}0.011 \pm \\
0.001\end{array}$ & $\begin{array}{l}0.015 \pm \\
0.001\end{array}$ & $\begin{array}{l}0.016 \pm \\
0.001\end{array}$ & $\begin{array}{l}0.021 \pm \\
0.002\end{array}$ \\
\hline & $\begin{array}{l}0.015- \\
0.018\end{array}$ & $\begin{array}{l}0.02- \\
0.03\end{array}$ & $\begin{array}{l}0.01- \\
0.012\end{array}$ & $\begin{array}{l}0.01- \\
0.02\end{array}$ & $0.015-0.018$ & $0.018-0.024$ \\
\hline \multirow[t]{2}{*}{$\begin{array}{l}\text { Esophagus ength } \\
\text { (muscular) }\end{array}$} & $\begin{array}{l}0.36 \pm \\
0.02\end{array}$ & $\begin{array}{l}0.43 \pm \\
0.02\end{array}$ & $\begin{array}{l}0.21 \pm \\
0.01\end{array}$ & $\begin{array}{l}0.30 \pm \\
0.02\end{array}$ & \multirow{2}{*}{$\begin{array}{l}0.33 \pm 0.01 \\
0.33-0.34\end{array}$} & \multirow{2}{*}{$\begin{array}{l}0.40 \pm 0.03 \\
0.34-0.47\end{array}$} \\
\hline & $\begin{array}{l}0.30- \\
0.42\end{array}$ & $\begin{array}{l}0.38- \\
0.48\end{array}$ & $\begin{array}{l}0.16- \\
0.26\end{array}$ & $\begin{array}{l}0.20- \\
0.40\end{array}$ & & \\
\hline \multirow{2}{*}{$\begin{array}{l}\text { Esophagus length } \\
\text { (granular) }\end{array}$} & $3.5 \pm 06$ & $5.2 \pm 0.5$ & $1.8 \pm 0.3$ & $2.8 \pm 0.3$ & $3.3 \pm 0.3$ & $3.4 \pm 0.3$ \\
\hline & $2.8-4.2$ & $4.2-6.2$ & $1.5-2.0$ & $2.2-3.4$ & $3.1-3.5$ & $3.1-3.8$ \\
\hline \multirow[t]{2}{*}{ Nerve ring* } & $\begin{array}{l}0.24 \pm \\
0.03\end{array}$ & $\begin{array}{l}0.22 \pm \\
0.02\end{array}$ & $\begin{array}{l}0.18 \pm \\
0.03\end{array}$ & $\begin{array}{l}0.18 \pm \\
0.03\end{array}$ & \multirow{2}{*}{$\begin{array}{l}0.19 \pm 0.03 \\
0.18-0.21\end{array}$} & \multirow{2}{*}{$\begin{array}{l}0.21 \pm 0.02 \\
0.20-0.23\end{array}$} \\
\hline & $\begin{array}{l}0.20- \\
0.28\end{array}$ & $\begin{array}{l}0.20- \\
0.24\end{array}$ & $\begin{array}{l}0.16- \\
0.21\end{array}$ & $\begin{array}{l}0.16- \\
0.21\end{array}$ & & \\
\hline \multirow[t]{2}{*}{ Excretory pore* } & $\begin{array}{l}0.3 \pm \\
0.02\end{array}$ & $\begin{array}{l}0.28 \\
\pm 0.01\end{array}$ & $\begin{array}{l}0.22 \pm \\
0.02\end{array}$ & $0.2 \pm$ & \multirow{2}{*}{$\begin{array}{l}0.27 \pm 0.02 \\
0.22-0.32\end{array}$} & \multirow{2}{*}{$\begin{array}{l}0.33 \pm 0.01 \\
0.32-0.34\end{array}$} \\
\hline & $\begin{array}{l}0.26- \\
0.34\end{array}$ & $\begin{array}{l}0.26- \\
0.30\end{array}$ & $\begin{array}{l}0.16- \\
0.28\end{array}$ & $\begin{array}{l}0.13- \\
0.27\end{array}$ & & \\
\hline \multirow[t]{2}{*}{ Preanal papillae } & \multicolumn{2}{|l|}{$8 \pm 0.2$} & \multicolumn{2}{|l|}{$11 \pm 0.3$} & $9 \pm 0.2$ & - \\
\hline & $7-9$ & - & $9-13$ & - & $7-9$ & \\
\hline \multirow[t]{2}{*}{ Spicule length (left) } & \multirow[t]{2}{*}{$\begin{array}{l}0.58 \pm \\
0.02\end{array}$} & & \multirow[t]{2}{*}{$\begin{array}{l}0.28 \pm \\
0.04\end{array}$} & & \multicolumn{2}{|l|}{$0.52 \pm 0.02$} \\
\hline & & - & & - & $0.50-0.54$ & - \\
\hline
\end{tabular}




\begin{tabular}{|c|c|c|c|c|c|c|}
\hline & $\begin{array}{l}0.48- \\
0.68\end{array}$ & & $\begin{array}{l}0.19- \\
0.38\end{array}$ & & & \\
\hline \multirow[t]{2}{*}{$\begin{array}{l}\text { Spicule length } \\
\text { (right) }\end{array}$} & $\begin{array}{l}0.012 \pm \\
0.001\end{array}$ & \multirow[b]{2}{*}{-} & $\begin{array}{l}0.1 \pm \\
0.02\end{array}$ & \multirow{2}{*}{-} & \multicolumn{2}{|l|}{$0.13 \pm 0.02$} \\
\hline & $\begin{array}{l}0.010- \\
0.015\end{array}$ & & $\begin{array}{l}0.09- \\
0.11\end{array}$ & & $0.13-0.14$ & - \\
\hline \multirow[t]{2}{*}{ Vulva length* } & & $8.1 \pm 0.8$ & & \multicolumn{2}{|c|}{$7.8 \pm 0.7$} & $7.0 \pm 0.4$ \\
\hline & - & $\begin{array}{l}5.20- \\
11.0\end{array}$ & - & $\begin{array}{l}5.10- \\
10.6\end{array}$ & - & $6.3-7.8$ \\
\hline \multirow[t]{2}{*}{ Tail length } & $\begin{array}{l}0.36 \pm \\
0.04\end{array}$ & $\begin{array}{l}0.29 \pm \\
0.03\end{array}$ & $\begin{array}{l}0.26 \pm \\
0.04\end{array}$ & $\begin{array}{l}0.21 \pm \\
0.02\end{array}$ & $0.41 \pm 0.03$ & $0.28 \pm 0.04$ \\
\hline & $\begin{array}{l}0.32- \\
0.40\end{array}$ & $\begin{array}{l}0.26- \\
0.32\end{array}$ & $\begin{array}{l}0.32- \\
0.40\end{array}$ & $\begin{array}{l}0.20- \\
0.22\end{array}$ & $0.39-0.43$ & $0.24-0.32$ \\
\hline
\end{tabular}

* Measurements are from anterior extremity;

\section{Discussion}

The marinka is a polyphage that consumes both plant and animal food in different seasons of the year (among which there is small trash fish), which contributes to the high infection of the fish with helminth species, especially during the period of post-spawning fish feeding (Najmidinov et al. 2020). The extreme western border of the mountains in northern Iran; the name of the Alay-Turkestan mountains in the Fergana Valley, called the Western Tien Shan, which stretches quite far to the east and is directly interconnected with the Himalayas, Tibet and other mountainous countries, and they are a considerably wide area of the marinka - a typical representative of the Mountainous Asian complex of ichthyofauna, which is at the same time the main carrier of the parazitofauna of fish (Osmanov 1971).

In our study, Rh. gnedini, Rh denudata and Rh. hellichi turkestanica were observed in intestine of the common marinka sampled in Vergana Valley. The results of the present study were similar to Karimov (2007), who noted a significantly high degree of infection of marinka with Rabdochona denudata, $R h$. gnedini and $R h$. chellichi in the river Isfara, Tajikistan. Rhabdochona hellichi occurs in mountain rivers, lakes and some foothill reservoirs in the Central Asia region (Karimov 2007). At the same time, it should be noted the presence of some morphs and geographical races of the indicated helminth, the distribution area of which is much wider. Rh. hellichi turkestanica reported from fish lived in Indian water bodies, as well as the morphologically close subspecies Rh. hellichi kurdistanensis is found in the local subspecies of the barbel in Iraq (Scholz 1995; Moravec et al. 2010; Chavan et al. 2014; Bilal et al. 2017).

Moravec et al. (2010) reported that $R h$. hellichi turkestanica were found in Schizothorax spp. (Cyprinidae, Cypriniformes), Rh. hospeti in Torspp. (Cyprinidae) and Rh. mazeedi in Clupisoma garua in India. They are carried out light and electron microscopic analysis made it possible to reveal new, previously unknown morphological and taxonomic characters and made it possible to describe this species again in 
more detail. Rh.hellichi turkestanica (synonym R. denudata filamentosa, $R$. kashmirensis, $R$. schizothoracis) was considered as a subspecies different from another typical subspecies $R$. hellichi hellichi mainly in the shape of the distal end of the left spicule, in molecular characteristics and geographic distribution. The morphology of the aforementioned species of Rhabdochona hardly differs from those of the original subspecies Rhabdochona hellichi. In the present study, the body of the parasite was narrowed at both ends. The cuticle was smooth. At the caudal end, females have a ring-shaped formation, the edges of which were dotted with spines. The lips were poorly developed, barely visible. The oral capsule was funnel-shaped. Very small cervical papillae were normal in shape. Thus, the Rhabdochona species we have characterized differ from each other in a number of morphologic characters, including the size of the body and spicule, the shape of the tail and egg.

Marinka lives in all surveyed mountain rivers and the Syrdarya river and adjacent water bodies of Western Fergana. However, the parasites were observed only sampled in the mountain rivers Rezaksay, Chodaksay and small tributaries of the Syrdarya river in western Fergana in the present study. Main factors of fish infectivity with parasite in the upper reaches of the Syrdarya are the rich hydrofauna and a wide range of fish nutrition: the latter, the marinka becomes infected with parasites by eating small trash fish; at the same time, the marinka, abundantly eating mayfly larvae which act as intermediate host of this parasites, so the fish is strongly infected with Rhabdochona species (Karimov 2007), which corresponds to the results of Stein (1959), who associates this phenomenon with an increase in the content of dissolved oxygen in the water and, as a rule, a strong infestation of mayfly larvae with larvae of Rhabdochona spp. Further, considering the reasons for the parasite infectivity of the marinka, indicates the adaptation of Rhabdochona spp. to the fast flow and low temperature of the water of mountain rivers, the relatively poor composition of animal food species, due to which the marinka switches to feeding benthic, along with which swallows larvae of Rhabdochona spp. (Karimov 2007). The flow rate is the leading factor in the formation of ichthyofauna and ichthyoparasite fauna of mountain rivers (Mukhamediev 1982). In the present study, it was pointed out that some abiotic factors such as the flow rate, water temperature and high content of dissolved oxygen in it, as well as the nutritional characteristics of the common marinka can be most important factors to spread of Rh.denudata, Rh. gnedini, Rh. hellichi turkestanica in marinka from mountain rivers of the Fergana Valley.

In conclusion, the marinka population sampled from the mountain rivers Rezaksay, Chodaksay and small tributaries of the Syrdarya river in western Fergana are infected with Rh.denudata, Rh. gnedini and $R h$. hellichi turkestanica. According to the Authors' knowledge, Rh. hellichi turkestanica was recorded in Uzbekistan for the first time. The flow rate, water temperature and high content of dissolved oxygen in rivers, and the nutritional characteristics of the marinka can be responsible for infection.

\section{Declarations}

Acknowledgments 
The authors would like to thank doctorate student National University of Uzbekistan Maqsadjon Madumarov for technical work of this manuscript.

\section{Statement of Authors Contributions}

AEK designed the project. Materials was collected EKhN and RRK. Original draft was written by AEK, AMM and KY. EKhN performed statistical analysis of data. All authors read and approved the final manuscript.

\section{Conflict of interest}

There are no conflicts of interest in our present study.

\section{References}

1. Agapova Al (1962) Parasites of fish of the upper and middle reaches of the Syrdarya river.Collection Institute zoology AN KazSSR, 16: 135-144.

2. Akramova FD, Azimov DA, Shakarboev EB et al. (2019) Ecological and faunistic analysis of Spirurida order nematodes - zooparasites of Uzbekistan. Russian Journal of Parasitology. 13 (3): 11-24.

3. Anderson RC (2000) Nematode parasites of vertebrates: their development and transmission. New York: CAB International, 650.

4. Bilal S, Abdullah SMA (2012) Two species of Rhabdochona (Nematoda: Rhabdochonidae) from the cyprinid fish Luciobarbus kersin (Heckel) in northern Iraq, including R. (Globochona) kurdistanensis sp.n. Folia Parasitologica 59 (2):139-47.

5. Bykhovskaya-Pavlovskaya IE (1985) Fish parasites. Study Guide. Leningrad,.

6. Chubb JC (1982) Seasonal occurrence of helminthes in freshwater fishes. Part 14. Adult Cestoda, Nematoda and Acanthocephala. Adv. Parasitol. 20: 1-292.

7. González Solís D, Chavan SA (2014) New species of Rhabdochona Railliet, 1916 (Nematoda: Rhabdochonidae) from cyprinid fishes in the Western Ghats Region, India. Systematic Parasitology, 87:273-281.

8. Karaev RM (1994) Epizootic state of the investigated water bodies. In the book. Kamilov et al. Water bodies of Uzbekistan and their fishery significance. Tashkent, 233-41.

9. Karimov SB (2007) Fish parasites of the Fergana Valley. Dissertaion for the degree of doctor of biological sciences. Tashkent, 187.

10. Moravec F, Scholz T, Ash A, Kar PK (2010). New data on the morphology and taxonomy of three species of Rhabdochona (Nematoda: Rhabdochonidae) parasitizing fishes in India. Folia Parasitologica, 57 (4): 295-306.

11. Mukhamediev MA (1982) Ichthyofauna and perspectives of fishery use of piedmont waterbodies of the Fergana Valley in connection with irrigation construction. Abstract of dissertation $\mathrm{PhD}$ in biological sciences. Leningrad. 
12. Najmiddinov EKh, Kuchboev AE., Mukhamediev AM (2020) Fauna of helminths of the common marinka Schizothorax eurystomus Kessler, 1872 in the upper reaches of the Syrdarya river. Uzbek Biological Journal, 5: 55-59.

13. Osmanov SO (1971) Fish parasites in Uzbekistan. Tashkent: Fan publishers, 530.

14. Safarova FE (2017) Helminths of fish of the Cyprinidae family of water bodies in the north-east of Uzbekistan. Astract dissertation PhD in biological sciences. Tashkent

15. Scholz T (1995) Life history of the nematode Rhabdochona hellichi, a parasite of the barbel in the Jihlava River, Czech Republic. Joumal of Helminthology, 69: 59-64.

16. Stein GA (1959) On the question of the life cycle and habitat of the nematode Rhabdochona denudata (Dujardin, 1845). Doklady Academy of Sciences of the USSR. 127 (6): 1320-1321

17. Vismanis KO, Lomakin VV, Roitman VD et al. (1987) In: Keys to parasites of freshwater fish of the fauna of the USSR. Edited by O.N.Bauer. Parasitic multicellular organisms. (The second part). Leningrad: Science, pp 218-240.

\section{Figures}

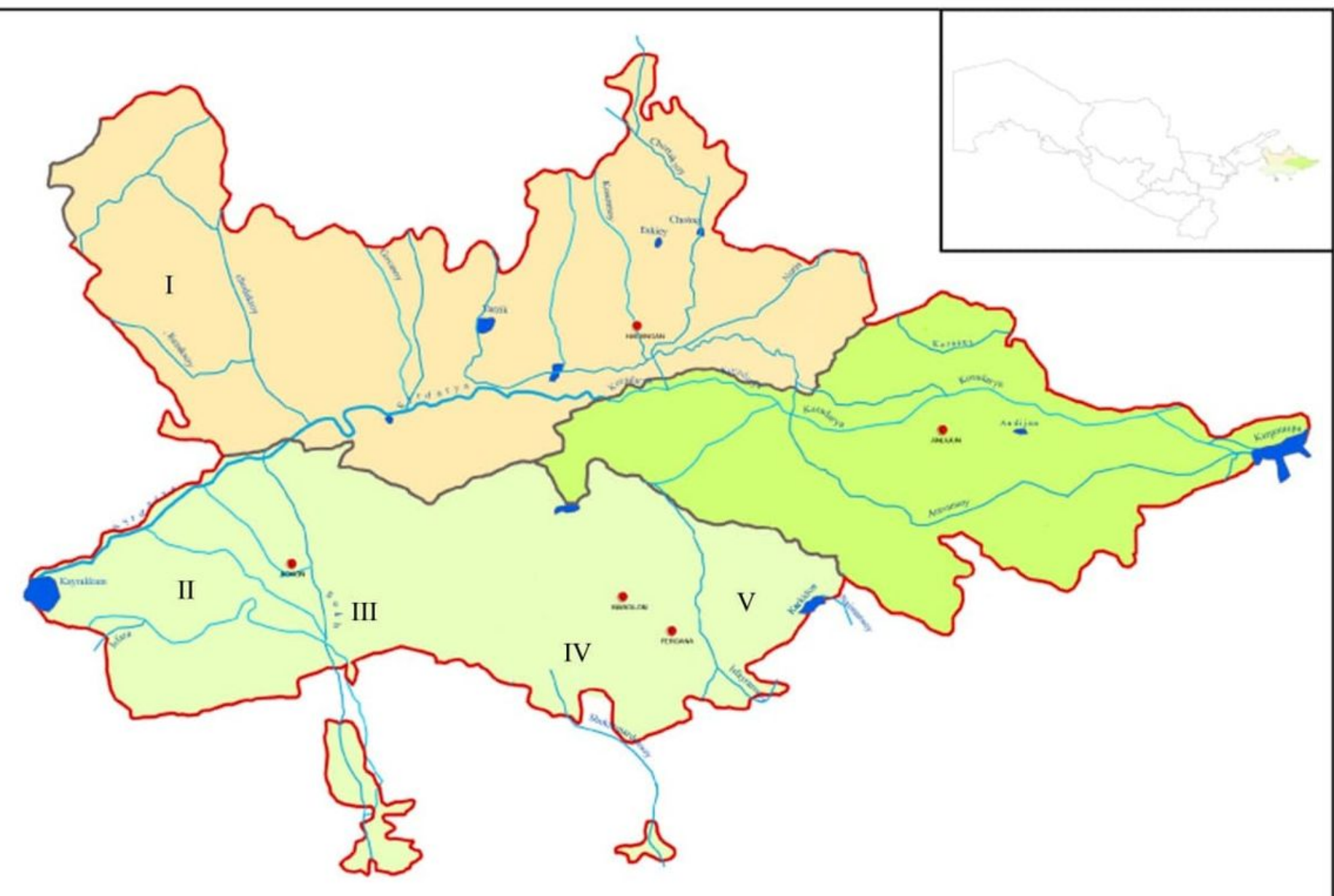

Scale: $1: 1500000$ 
Figure 1

Map of the water reservoirs of the Fergana Valley. Mountain rivers: I - Chodaksay, Rezaksay; III - Sokh; IV Isfayramsay; V - Shohimardansay; II- Western Fergana: Syrdarya river and adjacent reservoirs. Note: The designations employed and the presentation of the material on this map do not imply the expression of any opinion whatsoever on the part of Research Square concerning the legal status of any country, territory, city or area or of its authorities, or concerning the delimitation of its frontiers or boundaries. This map has been provided by the authors.
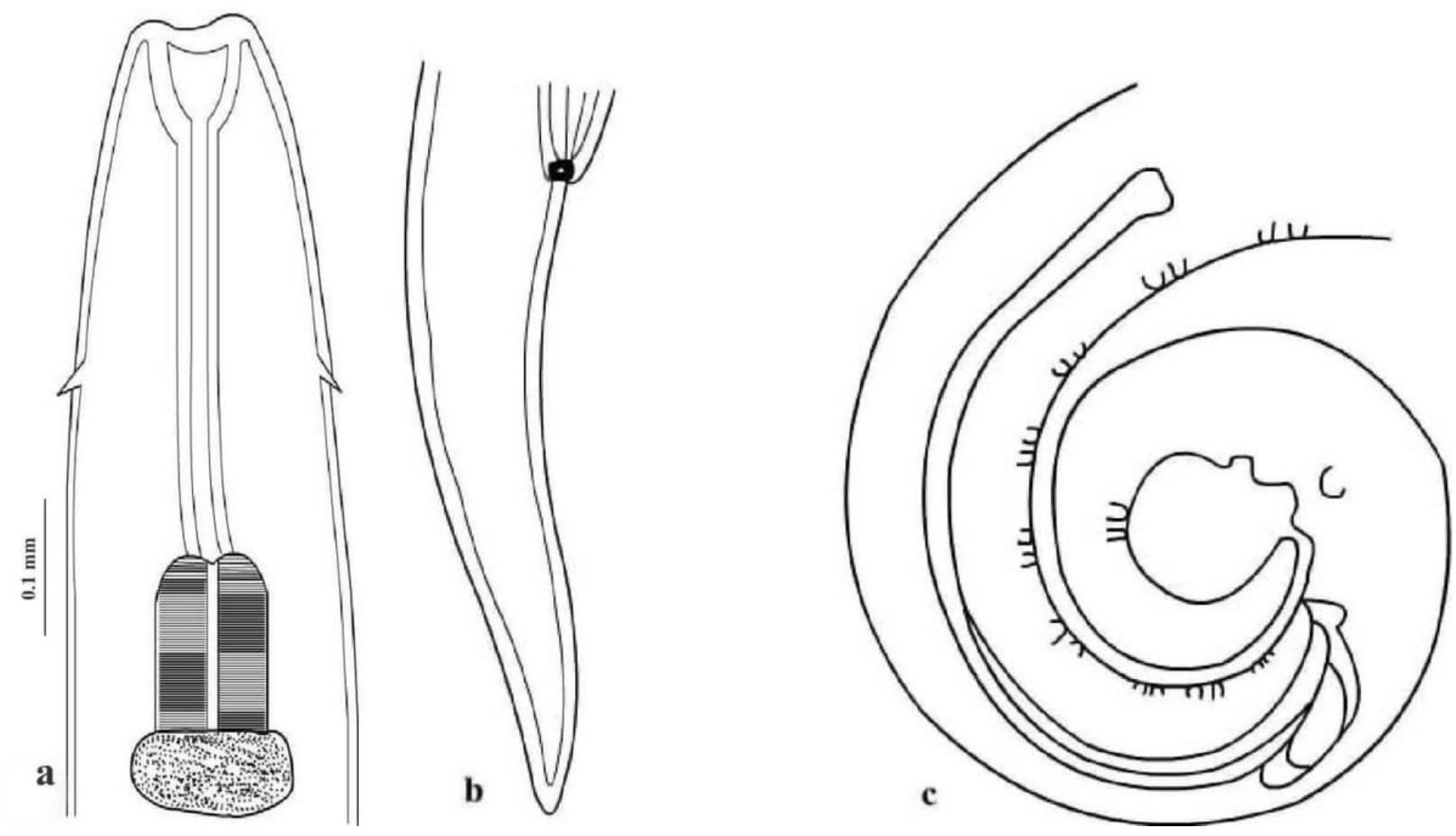

Figure 2

Rhabdochona gnedini: a - the front end of the body, dorsally; $b$ - tail end of the male body; $c$ - tail end of the body female, laterally (original). 

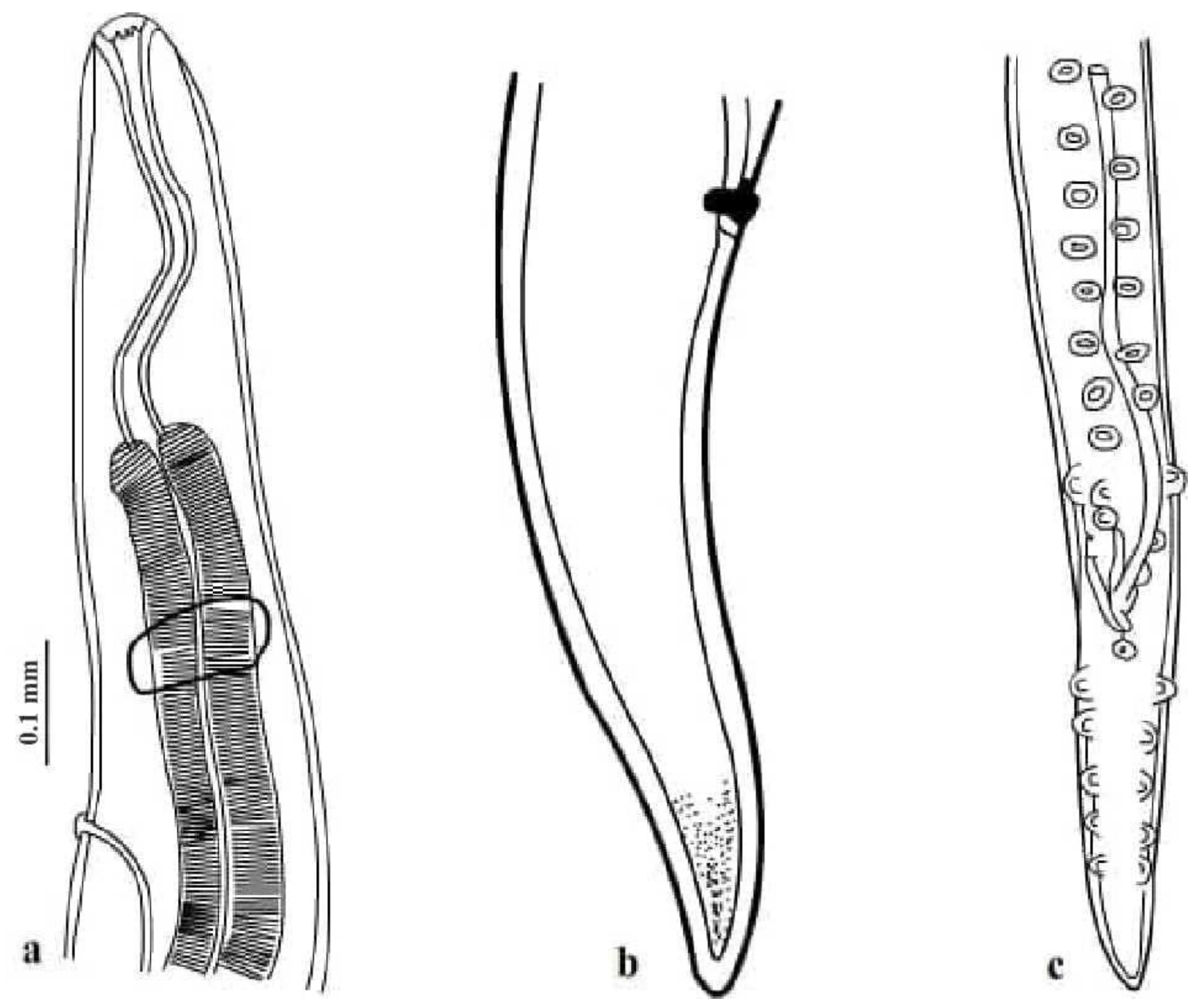

Figure 3

Rhabdochona denudata: $a$ - the front end of the body, laterally; $b$ - tail end of the body female, laterally; c tail end of the male body, ventrally (original). 

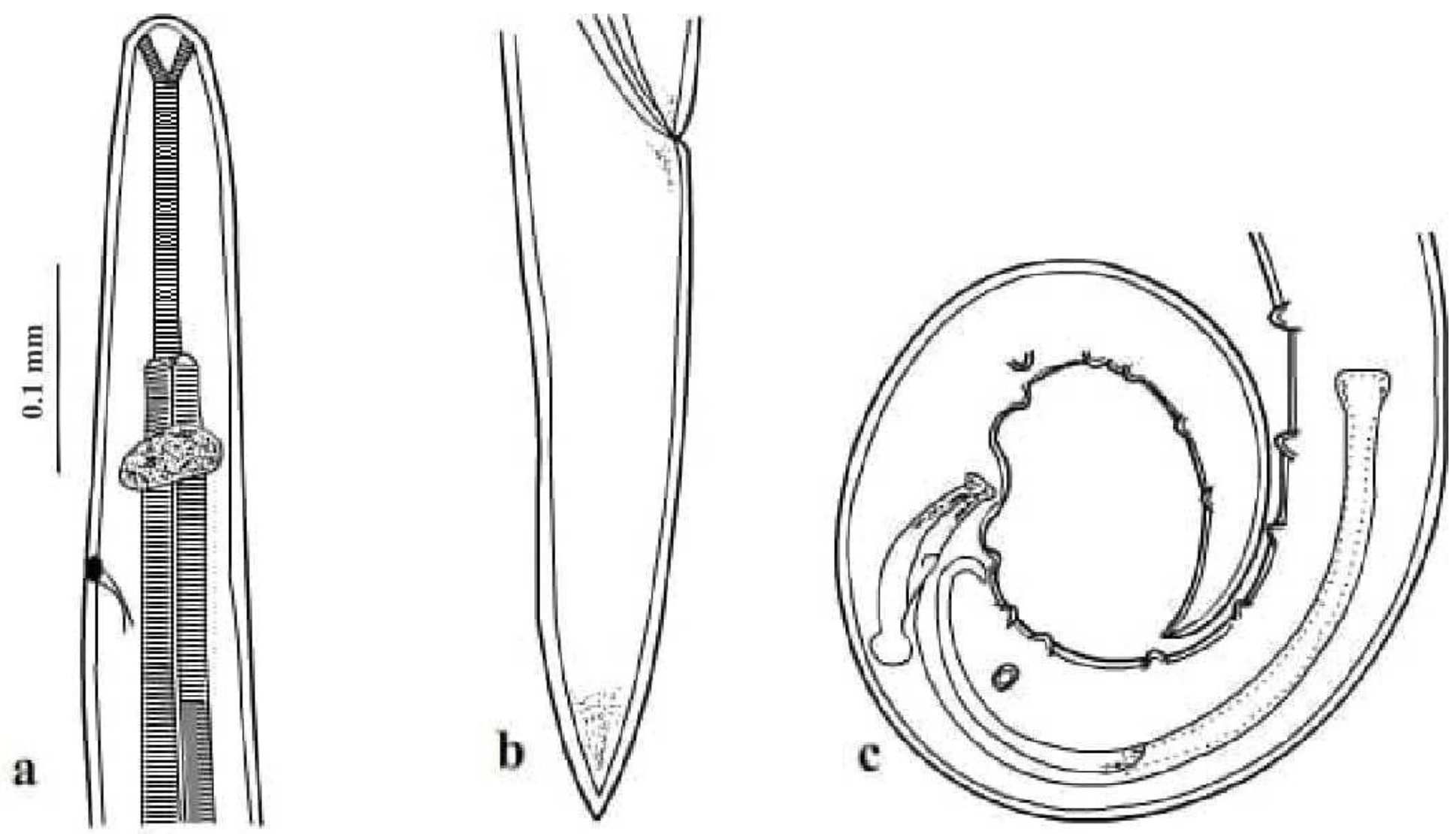

Figure 4

Rhabdochona hellichi turkestanica: $a$ - the front end of the body, laterally; $b$ - tail end of the body female, laterally; c - tail end of the male body, laterally (original). 